\title{
Heterotrophic soil respiration and soil carbon dynamics in the deciduous Hainich forest obtained by three approaches
}

\author{
Werner L. Kutsch • Tryggve Persson • Marion Schrumpf • \\ Fernando E. Moyano • Martina Mund • \\ Stefan Andersson · Ernst-Detlef Schulze
}

Received: 16 February 2009/Accepted: 4 February 2010/Published online: 6 March 2010

(C) The Author(s) 2010. This article is published with open access at Springerlink.com

\begin{abstract}
Three different approaches were used to calculate heterotrophic soil respiration (Rh) and soil carbon dynamics in an old-growth deciduous forest in central Germany. A root and mycorrhiza exclosure experiment in the field separated auto- and heterotrophic soil respiration. It was compared to modeled heterotrophic respiration resulting from two different approaches: a modular component model of soil respiration calculated autotrophic and heterotrophic soil respiration with litter, climate and canopy photosynthesis as input variables. It was calibrated by independent soil respiration measurements in the field. A second model was calibrated by incubation of soil
\end{abstract}

\footnotetext{
W. L. Kutsch ( $\square)$

Johann Heinrich von Thünen Institut (vTI), Institute of Agricultural Climate Research, Bundesallee 50, 38116 Braunschweig, Germany

e-mail: werner.kutsch@vti.bund.de
}

W. L. Kutsch · M. Schrumpf · F. E. Moyano ·

M. Mund · E.-D. Schulze

Max-Planck-Institute for Biogeochemistry,

P.O. Box 1001 64, 07701 Jena, Germany

\section{T. Persson}

Department of Ecology, Section of Soil Ecology,

Swedish University of Agricultural Sciences,

Box 7044, 75007 Uppsala, Sweden

\section{S. Andersson}

Department of Soil and Environment,

Swedish University of Agricultural Sciences,

Box 7014, 75007 Uppsala, Sweden samples from different soil layers in the laboratory. In this case, the annual sum of $\mathrm{Rh}$ was calculated by an empirical model including response curves to temperature and a soil moisture. The three approaches showed good accordance during spring and summer and when the annual sums of Rh calculated by the two models were compared. Average Rh for the years 2002-2006 were $436 \mathrm{~g} \mathrm{C} \mathrm{m}^{-2}$ year $^{-1}$ (field model) and $417 \mathrm{~g} \mathrm{C} \mathrm{m}^{-2}$ year $^{-1}$ (lab-model), respectively. Differences between the approaches revealed specific limitations of each method. The average carbon balance of the Hainich forest soil was estimated to be between 1 and $35 \mathrm{~g} \mathrm{C} \mathrm{m}^{-2}$ year ${ }^{-1}$ depending on the model used and the averaging period. A comparison with nighttime data from eddy covariance (EC) showed that EC data were lower than modelled soil respiration in many situations. We conclude that better filter methods for EC nighttime data have to be developed.

Keywords Soil respiration - Soil organic matter . Flux partitioning · Eddy covariance

\section{Introduction}

Soil carbon fluxes and resulting carbon stocks depend on several closely connected processes. Carbon inputs via litterfall and fine-root litter production in natural ecosystems are mainly controlled by plant primary production. Mineralisation of soil organic 
matter depends on temperature and water conditions, quality of organic matter (Davidson et al. 2006; Hyvönen et al. 2007; Kutsch et al. 2009a), and on complex stabilization processes in the soil that protect soil organic matter, for limited time periods, against microbial decomposition (von Lützow et al. 2007; Kögel-Knabner et al. 2008). In the long run, microbial decomposition is controlled by the ecophysiological features of the microbiota which themselves can be defined as the result of adaptation to the environment (Kutsch et al. 2009b).

Traditionally, soil carbon stock changes have been determined by repeated analyses of soil samples ('repeated stocktaking'). The problem of this method is the detection of small expected changes against high "background" and huge spatial variability of carbon stocks and influencing soil parameters. Thus, long time periods up to several decades might be necessary to be able to detect significant changes in soil carbon unless a very high sampling effort is made (Smith 2004; Schrumpf et al. 2008).

However, robust estimates of carbon stock change for shorter periods between 1 and 5 years are highly demanded for at least three reasons.

(1) Creeping losses or gains of soil carbon due to climate or land use change that are too small to be detected by repeated stocktaking,

(2) possible accounting of soil carbon stock changes in the Kyoto framework,

(3) validation of eddy covariance results in combination with inventories of aboveground biomass changes.

The balance between carbon inputs with organic matter and outputs via mineralisation of soil organic carbon and leaching of dissolved and particulate organic carbon determines changes in soil carbon stocks. Assuming that leaching of dissolved organic carbon (DOC) is only of minor importance in well buffered soils, the difference between litter input and the mineralisation of soil organic matter, also called 'heterotrophic soil respiration' (Rh), can be used as an estimate for soil carbon changes. Usually only total soil respiration (Rs) can be directly measured in the field. Rs consists of $\mathrm{Rh}$ and a flux of $\mathrm{CO}_{2}$ resulting from the respiration of assimilates transferred directly to the roots and mycorrhizal fungi via the phloem-the so called 'rhizospheric' or 'autotrophic' respiration (Ra, Kutsch et al. 2009a; Moyano et al. 2009). The separation of these fluxes requires special experimental setups/manipulations like root exclosure experiments (Subke et al. 2006), girdling (Högberg et al. 2001) or measurements of soil samples in the laboratory (Persson et al. 2000). Since all approaches to estimate heterotrophic soil respiration have their own limitations, cross-comparison between methods is highly demanded.

The objective of this study is to compare three different approaches to determine heterotrophic soil respiration and soil carbon dynamics in an undisturbed old-growth deciduous forest in Thuringia, Germany. The following approaches were applied:

(1) A modular component model of soil respiration that calculates autotrophic and heterotrophic soil respiration with litter, climate and canopy photosynthesis as input variables and that was calibrated by independent soil respiration measurements in the field,

(2) root and mycorrhiza exclosure experiment in the field to separate auto- and heterotrophic soil respiration that was compared to modelled heterotrophic respiration resulting from the model described in point (1), and

(3) incubation of soil samples (excluding living roots and coarse woody litter) from different soil layers in the laboratory where the annual sum of $\mathrm{Rh}$ is calculated by an empirical model including response curves to temperature and soil moisture.

The goal is to receive robust estimate of heterotrophic respiration for the calculation of mid-term (58 years) soil carbon stock changes. In addition, the results of the total soil respiration model (point 2) were compared to nighttime fluxes obtained from an eddy covariance system at the Hainich site.

\section{Materials and methods}

Study site

The study was conducted in the "Hainich National Park" in central Germany $\left(51^{\circ} 04^{\prime} 46^{\prime \prime} \mathrm{N}, 10^{\circ} 27^{\prime} 08^{\prime \prime} \mathrm{E}\right.$, $440 \mathrm{~m}$ a.s.1.). Annual rainfall amounts range between 750 and $800 \mathrm{~mm}$, and mean annual air temperatures are $7.5-8^{\circ} \mathrm{C}$. The forest is dominated by beech (Fagus sylvatica, 65\%), ash (Fraxinus excelsior, 25\%), and 
maple (Acer pseudoplatanus and A. platanoides, 7\%), other deciduous and coniferous species are interspersed. Trees cover a wide range of age classes with a maximum of 250 years. Maximum tree height varies between 30 and $35 \mathrm{~m}$, and the leaf area index is $4.8 \mathrm{~m}^{2} \mathrm{~m}^{-2}$. Large amounts of standing dead wood and coarse woody debris are characteristic for this semi-natural forest, which was taken out of management about 60 years ago due to the establishment of a military base and is now protected as a national park. The ground vegetation is dominated by Geophytes and Hemicryptophytes and was classified as a Hordelymo-Fagetum (according to Oberdorfer 1994).

The bedrock for soil formation was Triassic limestone overlain by a Pleistocene loess layer of varying thickness $(10-50 \mathrm{~cm})$. Soils are classified as eutric Cambisols (WRB IWG 2007). The organic layer is a mull or F-Mull (Oi- and thin Oe-layer) and indicates a high biological activity of the soil fauna. Hainich Forest is a main site of the integrated project CarboEurope. In order to relate the net ecosystem exchange (NEE) estimates obtained from eddy covariance data to changes in biomass, soil carbon stocks, and heterotrophic respiration, the main footprint of the tower was chosen as study site. The footprint of eddy covariance measurements is defined by wind direction and wind speed. The average wind distribution (Fig. 1) shows that the main footprint of the flux measurements at Hainich is located southwest of the tower. Knohl et al. (2008) who used data from a previous study by Søe and Buchmann (2005) for identifying the heterogeneity of the soil concluded that about 50 randomly located measurements are needed to obtain a precision of $\pm 5 \%$ for the average soil respiration estimate.

\section{Sampling design}

The study design is shown in Fig. 1. All sampling points were placed southwest of the tower. Soil sampling was conducted in the years 2000 and 2004 mainly in the framework of the European projects FORCAST and CarboEurope-IP (CEIP). For mineralisation experiments within the FORCAST project, litter and soil samples were taken in 2000 at nine anchor points within a relatively small area Southwest of the flux tower (Fig. 1). The litter was collected from each point by a $25 \times 25 \mathrm{~cm}$ frame. Underneath, the $0-5$ and $5-10 \mathrm{~cm}$ layers of the mineral soil were sampled by a $100 \mathrm{~cm}^{2}$ metal frame.
Fig. 1 Map of flux tower area in the Hainich National Park, the wind direction distribution (in percent of total annual number of measurements), and the supplemental measurements within the footprint area. The background is a satellite picture of the area provided by Google Earth




Below $10 \mathrm{~cm}$ depth, a corer with a cutting edge of $32.17 \mathrm{~cm}^{2}$ was used down to $30 \mathrm{~cm}$. Because of logistic constraints, samples were pooled for mineralisation experiments (samples from points $1+2$, $3+4,5+6$ were pooled pair-wise, and the three samples from points 7-9 were pooled), implying that the FORCAST sampling led to four composite replicates for analyses.

At the beginning of the CarboEurope project in March 2004, 100 soil cores covering a much larger part of the footprint area (Fig. 1) of the tower were taken using a soil column cylinder auger by Eijkelkamp. The cylinder is driven into soil with a mechanical hammer causing only minor compression of the soil column and allows for the collection of rather undisturbed soil samples with a diameter of $8.7 \mathrm{~cm}$. This method enables the determination of bulk densities at the collected soil samples. Samples were divided into $10 \mathrm{~cm}$ segments with the exception of $0-5$ and $5-10 \mathrm{~cm}$ to a depth of $60 \mathrm{~cm}$. Before soil coring, the litter layer was collected separately for $\mathrm{Oi}$ and Oe/Oa layers using a $25 \times 25 \mathrm{~cm}^{2}$ frame. Out of the 100 sampling points, 10 were randomly chosen for more detailed analyses like texture or mineralisation experiments.

\section{Soil respiration in the field}

Measurements of total soil respiration in the field were conducted discontinuously along a transect with 14 plots within the tower footprint that was installed in early 2004 (Fig. 1). Since each plot consisted of four collars, 56 collars were measured in total. Collars were inserted less than $1 \mathrm{~cm}$ into the topsoil and fixed with three spikes per collar. Measurements were conducted biweekly during the growing season and monthly during winter.

Soil respiration measurements were done with a soil chamber and infrared gas analyzer (LICOR LI6400-09, Licor Inc., Lincoln, NE, USA). At each collar the measurement was repeated three times and measured flux rates were averaged. For quality control of the measurements the standard deviation of the three repetitions was calculated. When standard deviation was higher than $15 \%$ of the average flux rate the data were discarded assuming a disturbance by the measurement. This was the case with $5 \%$ of the measurements in 2004 and $9.7 \%$ of the measurements in 2005. One campaign in 2005
(August 8) was completely discarded, because 22 of 56 measurements failed the quality test. In 2006 the procedure was changed: the quality check was run immediately in the field and measurements with high standard deviations were repeated after about $20 \mathrm{~min}$.

Modelling soil respiration from field data

Soil respiration was modeled by a decomposition model describing $\mathrm{Rh}$ developed by Kutsch and Kappen (1997) that was completed by a model of autotrophic respiration (Ra) after Kutsch et al. (2001). The decomposition model comprised two layerslitter and topsoil. For each layer, the decomposition rate depended on soil temperature $(2 \mathrm{~cm}$ depth for litter and $5 \mathrm{~cm}$ for the topsoil) and moisture (mean of 4 TDR-probes at $8 \mathrm{~cm}$ depth for both layers) measured continuously at the site, on the amount of carbon available and on the soil quality reflected by different rate constants. The model also allows to describe temperature acclimation and the effects of drought and re-wetting by increasing the $Q_{10}$ (Kutsch and Kappen 1997). The threshold of the soil moisture response function was set to $60 \%$ of field capacity. Above that threshold no influence of soil moisture was modelled, because a significant reduction of soil respiration at high soil moisture was never measured in the field.

Autotrophic respiration (Ra) was modelled for three different root diameter classes (coarse $>10 \mathrm{~mm}$, intermediate $2-10 \mathrm{~mm}$, and fine roots $<2 \mathrm{~mm}$ ). Many studies have shown that fine root biomass and activity are strongly depending on assimilates provided by actual photosynthesis (Moyano et al. 2009). In order to model the seasonal dynamics but to keep the model simple, we included seasonal changes in the fine root biomass while the activity per biomass was kept constant (Fig. 2). A part of the biomass was kept constant and was present and active also during winter time. The variable part was calibrated by means of information from the eddy covariance measurements (numbers) and the soil respiration measurements (letters): the shape of the curve was defined by onset (1), peak (2) and end (3) of the growing season, (defined by daytime $\mathrm{CO}_{2}$ uptake from the eddy covariance data) the absolute amount (A, B) was calibrated by finding the optimum fit to the field measurements of soil respiration. This model is further referred to as 'field model'. 


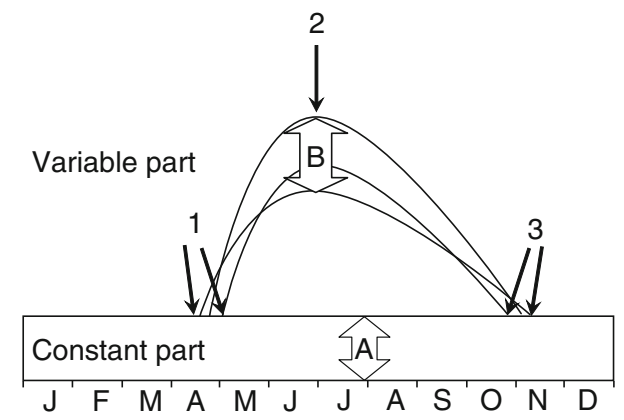

Fig. 2 Scheme of the calibration procedure of the autotrophic part of the modular soil respiration model (field model). The seasonal dynamics was modeled by changes in the fine root biomass while the activity per biomass was kept constant. A part of the biomass was kept constant and was present and active also during wintertime. The variable part was calibrated by means of information from the eddy covariance measurements (numbers) and the soil respiration measurements (letters): the shape of the curve was defined by onset (1), peak (2) and end (3) of the growing season, defined by uptake from the eddy covariance data; the absolute amount $(A, B)$ was calibrated by finding the optimum fit to the field measurements of soil respiration

Root and mycorrhiza exclosure experiment

In an additional experiment, soil respiration was partitioned by excluding roots or roots and mycorrhizal hyphae from soil cores using nylon mesh bags of 35 and $1 \mu \mathrm{m}$ pore size, respectively, (Moyano et al. 2007, 2008). Soil cores (30 cm deep and $15 \mathrm{~cm}$ diameter) were removed and restored intact inside mesh bags. 25 plots were installed at random points falling on a grid of $60 \times 60 \mathrm{~m}$ within the footprint area of the tower. Each plot consisted of both mesh bag treatments and an additional control for measuring total Rs. Respiration fluxes from the rhizosphere, mycorrhiza and soil organic matter were estimated by subtracting values of soil respiration measured in the collars. For this study, only results from the $1 \mu \mathrm{m}$ mesh bags, representing the heterotrophic respiration (Rh) of the soil, were used. Measurements within the partitioning experiment were conducted only in 2006, starting immediately after snow melt (late March), and were carried out every 2 nd week until November.

Soil water content in the upper $6 \mathrm{~cm}$ (Theta Probe, Delta-T Devices Ltd., Cambridge, UK) and soil temperature at $5 \mathrm{~cm}$ depth were measured at the plot level along with each soil respiration measurement. Continuous soil temperature and moisture measurements at different depths were conducted next to the eddy covariance tower.

Soil carbon analyses

Soil samples of the 10 special soil cores of the CarboEurope soil sampling 2004, coarse roots (diameter $>10 \mathrm{~mm}$ ) and stones were removed before a subsample of about $200 \mathrm{~g}$ was separated and stored cold $\left(2^{\circ} \mathrm{C}\right)$ before mineralisation analyses. The remaining sample material was air-dried and afterwards also sieved to $2 \mathrm{~mm}$ and bulk density (BD) was determined. Total carbon content was determined on ball-milled soil samples by dry combustion using a Vario MAX CN (Elementar). The inorganic carbon content of the samples was determined after destruction of organic carbon in a muffle furnace for $16 \mathrm{~h}$ at $450^{\circ} \mathrm{C}$, followed by another carbon analysis by dry combustion. The difference between inorganic and total carbon was considered to be organic carbon.

Dry matter of litter samples was determined at $70^{\circ} \mathrm{C}$ after removal of about $100 \mathrm{~g}$ field-moist litter for mineralisation experiments, while litter of the FORCAST sampling was dried at $105^{\circ} \mathrm{C}$ for $24 \mathrm{~h}$. Total organic carbon content was determined after grinding and milling the samples.

\section{Mineralisation experiments}

Field-moist subsamples of the FORCAST and CarboEurope sampling were used for mineralisation experiments. Fresh litter samples (Oi) were sorted by hand, excluding living green parts like mosses but including branches to a diameter of $1 \mathrm{~cm}$. All other samples were sieved to $2 \mathrm{~mm}$, removing roots, stones and buried branches. Dry matter (dw) was determined on a subsample after drying at $105^{\circ} \mathrm{C}$ for $24 \mathrm{~h}$. Losson-ignition (LOI) was determined after combusting the dried samples at $550^{\circ} \mathrm{C}$ for $3 \mathrm{~h}$. Total $\mathrm{C}$ and $\mathrm{N}$ concentrations were determined in a Carlo-Erba NA 1500 Analyzer. When sample $\mathrm{pH}$ was $>6$, ash samples from the LOI determination were analysed for $\mathrm{C}$ concentration in the Carlo-Erba at $1,000^{\circ} \mathrm{C}$ to determine the difference between the two temperatures. The difference was considered as carbonate $\mathrm{C}$.

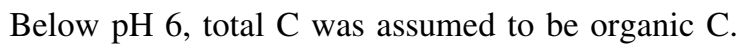

After sample preparation, which was finished after about 3 weeks, litter, humus and mineral soil subsamples (corresponding to 6, 16 and $100 \mathrm{~g}$ dry wt., 
respectively) were placed in plastic jars $\left(50 \mathrm{~cm}^{2}\right.$ surface area, $466 \mathrm{~cm}^{3}$ volume). The jars had a lid with a 5-mm diameter aperture for gas exchange. These soil microcosms were incubated in the laboratory at constant temperature $\left(15^{\circ} \mathrm{C}\right)$ and moisture (60\% WHC, water-holding capacity). Distilled water was added once a month to keep the water content in the samples constantly high. A whole incubation period lasted for 130 days (FORCAST) or 21 days (CarboEurope). $\mathrm{CO}_{2}$ measurements were performed once a week during the first month, every second week the next month and every fourth week the following months (FORCAST).

To determine $\mathrm{C}$ mineralisation $\left(\mathrm{CO}_{2}\right.$ evolution) in the litter and soil materials, the containers were periodically closed with airtight lids with a rubber septum. Background gas samples were taken after 15 min from the headspace with a syringe and were injected into a gas chromatograph (Hewlett Packard 5890, HP Company, Avondale, PA, USA). The measurement was repeated when an appropriate amount of $\mathrm{CO}_{2}$ had accumulated in the jars, from $120 \mathrm{~min}$ to $24 \mathrm{~h}$, depending on the respiration rate. The mass of $\mathrm{C}$ evolved per jar $\left(R_{\mathrm{C}}\right)$ was calculated with Eq. 1 according to Persson (1989):

$R_{\mathrm{C}}=\frac{12 \cdot 106 \cdot\left(C-C_{0}\right) \cdot p \cdot\left(\frac{V_{g}}{R T}+A \cdot V_{a q}\right)}{t}$

where $R_{\mathrm{C}}$ is the $\mu \mathrm{g} \mathrm{C} \mathrm{jar}{ }^{-1} \mathrm{~h}^{-1}, C$ the final conc. of $\mathrm{CO}_{2}\left(\mathrm{~cm}^{3} \mathrm{~cm}^{-3}\right), C_{0}$ the background $\mathrm{CO}_{2}$ conc. $\left(\mathrm{cm}^{3} \mathrm{~cm}^{-3}\right)$ in the jar, $t$ the time between background and final gas sampling (h), $V_{g}$ the gas volume $\left(\mathrm{cm}^{3}\right)$ in the jar, $V_{a q}$ the water volume $\left(\mathrm{cm}^{3}\right)$ in the jar and $A$ is the $\mathrm{pH}$-dependent $\mathrm{CO}_{2}$-absorption factor, where:

$A=K_{1}+\frac{K_{1} \cdot K_{2}}{\left(H^{+}\right)}+\frac{K_{1} \cdot K_{2} \cdot K_{3}}{\left(H^{+}\right)^{2}}$

and $K_{1}$ (Henry's law constant) $=7.79 \times 10^{-2}\left(\mathrm{~mol} \mathrm{l}^{-1}\right.$ $\left.\mathrm{atm}^{-1}\right), \quad K_{2}=3.81 \times 10^{-7}\left(\mathrm{~mol} \mathrm{l}^{-1}\right), \quad K_{3}=3.71 \times$ $10^{-11}\left(\mathrm{~mol} \mathrm{l}^{-1}\right)$ (all values given for $288.15 \mathrm{~K}$ ) and $\left(\mathrm{H}^{+}\right)=10^{-\mathrm{pH}}\left(\mathrm{mol} \mathrm{l}^{-1}\right), p$ is the atm pressure (atm) when the jars were closed, $R$ the gas constant (82.05)

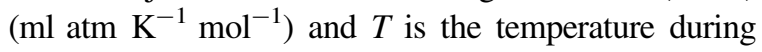
incubation $(288.15 \mathrm{~K})$.

$\mathrm{C}$ mineralisation rates were generally expressed as $\mathrm{g} \mathrm{CO}_{2}-\mathrm{C} \mathrm{g}^{-1} \mathrm{C} \mathrm{day}^{-1}$, and data on the $\mathrm{C}$ pools in each soil layer enabled us to calculate $\mathrm{C}$ mineralisation rates per $\mathrm{m}^{2}$. Because roots and mycorrhizal mycelia were partly removed by sieving, and since there was a delay of 3-4 weeks between sampling and start of incubation, we considered the estimated $\mathrm{C}$ mineralisation to be of heterotrophic and not autotrophic origin. In addition, we assume that some of the potential maximum rate of heterotrophic mineralisation was probably not measured, since the soils were respiring for 3 weeks before the measurements were started.

Modelling soil respiration from

lab incubation data

To obtain estimates of field $\mathrm{C}$ mineralisation (heterotrophic respiration, $R_{\mathrm{h}}$ ), the incubation flux rates obtained per g C per soil layer and day (see 'Results') were multiplied by (i) the amount of $\mathrm{C}$ per soil layer, (ii) a temperature-dependent factor $\left(F_{\mathrm{ST}}\right)$ and (iii) a moisture-dependent factor $\left(F_{\mathrm{SM}}\right)$. $F_{\mathrm{ST}}$ (Eq. 3) was calculated for each soil layer and month (Persson et al. 2000) with input data from soil temperatures (ST) measured at 2, 5, 15, 30 and $50 \mathrm{~cm}$ depth. $F_{\mathrm{SM}}$ (Eq. 4) was calculated for each soil layer and month with input data from measurements of soil moisture $(\mathrm{SM})$ at 8,16 and $32 \mathrm{~cm}$ depth. The response function for soil moisture $\left(F_{\mathrm{SM}}\right)$ was based on Seyferth (1998), who found a linear relation between relative water content $(x)$ and $\mathrm{C}$ mineralisation rate.

$F_{\mathrm{ST}}=\frac{\left(S T-S T_{\min }\right)^{2}}{\left(T_{\text {ref }}-S T_{\text {min }}\right)^{2}}$

$F_{\text {SM }}=0.8 x+0.2$

where $S T$ is the soil temperature in the field $\left({ }^{\circ} \mathrm{C}\right)$, $S T_{\text {min }}$ is $-6.2\left({ }^{\circ} \mathrm{C}\right), T_{\text {ref }}$ is the lab incubation temperature $\left(15^{\circ} \mathrm{C}\right)$, and $x=$ fraction of optimum soil moisture (our lab condition of $60 \%$ WHC was considered as 1 as well as the winter moisture at Hainich of $40 \%$ water content). This model is further referred to as 'lab model'.

Eddy covariance measurements

Ecosystem net carbon and water vapour fluxes were measured continuously since 1999 with an eddy covariance system consisting of a sonic anemometer (Solent R3, Gill Instruments, Lymington, UK) mounted at $43.5 \mathrm{~m}$ and a LI 6262 infrared gas analyser (LiCor, Lincoln, NE, USA) located at the 
base of the tower. The air was pumped through a $50 \mathrm{~m}$ tube (Dekabon, SERTO Jakob, Fuldabrück, Germany) and filtered behind the inlet and a second time before the gas analyser (ACRO 50 PTFE $1 \mu \mathrm{m}$ pore-size, Gelman, Ann Arbor, MI, USA). For more details about the instrumentation we refer to Knohl et al. (2003) and Anthoni et al. (2004).

The flux data were calculated for $30 \mathrm{~min}$ intervals by means of the post-processing software package 'eddysoft' (Kolle and Rebmann 2007). Raw data were converted into physical data and detrended and a planar-fit rotation after Wilczak et al. (2001) was applied. Time lags for $\mathrm{CO}_{2}$ and water vapour concentrations were calculated by determining the maximum correlation between the fluctuations of the concentrations and the vertical wind component $w$ '. The fluxes were calculated using conventional equations (Desjardins and Lemon 1974; Moncrieff et al. 1997; Aubinet et al. 2000; Knohl et al. 2003). The $\mathrm{CO}_{2}$ flux into and out of the storage was determined as the time change within a $\mathrm{CO}_{2}$ profile where concentrations were measured continuously at nine heights. The atmospheric stability was characterized by the Monin-Obukhov stability parameter $\zeta$ which was obtained by dividing the measuring height above displacement height $\left(z_{m}\right)$ by the Monin-Obukhov length (L). Stable conditions were assumed when $\zeta$ was higher than 0.065 , unstable when $\zeta$ was lower than -0.065 . Values in between characterize neutral conditions.

Gaps resulting from system maintenance or low data quality were filled by the so-called MDS procedure offered by the CarboEurope database services (Reichstein et al. 2005). Datasets filled after that procedure, are called Level-4-data.

\section{Above- and belowground litter input}

The annual production of leaves, bud scales and fruits were taken for 2000 from Mund (2004), for 2001 and 2002 from Cotrufo (2003) and for 2003-2007 it was derived from continuous litter sampling in 29 traps (each $0.5 \mathrm{~m}^{2}$ ) distributed over the main footprint (Fig. 1). Woody litter fall was not included as twigs and branches were removed for the soil respiration measurements and for soil incubation. Litter was sampled every 2 weeks from October to November and every 2 months over the rest of the year. The samples were dried at $70^{\circ} \mathrm{C}$ for 3 days and weighed.
Mean carbon concentration of leaves was $48.2 \pm$ $6.2 \%$, and that of fruits $50 \pm 4.8 \%$ (nuts and shells, total combustion, elemental analyzer "VarioEL II", 1998, Elementar Analyse GmbH, Hanau, Germany).

Mean fine-root litter production was derived from repeated field measurements at the study site in 2002, and several other campaigns at beech forests within Europe, resulting in a mean ratio of leaf to fine root production of about 0.9 that was used for all other years of the studied period (Claus pers. comm.; Claus and George 2005; Cotrufo pers. comm.; Matteucci pers. comm.; Mund 2004). Litter input by ground vegetation equals the maximum biomass resulting from a repeated above- and belowground biomass sampling in 2000 (Graef and Gebauer pers. comm.) minus perennial rhizome biomass, and assuming a constant litter input by ground vegetation over the entire study period.

\section{Results}

\section{Soil characterization}

Soil characteristics obtained in 2004 to a depth of $60 \mathrm{~cm}$ are given in Table 1 . Soil $\mathrm{pH}$ was equal to or slightly above 6 in all soil layers. Organic $\mathrm{C}$ and total $\mathrm{N}$ concentrations as well as $\mathrm{C} / \mathrm{N}$ ratios decreased with increasing soil depth, while inorganic $\mathrm{C}$ concentrations increased. As a consequence, organic $\mathrm{C}$ stocks at deeper soil layers were smaller than in the upper layers despite higher bulk densities in the subsoil.

Field measurements and resulting model

Total soil respiration in the field showed the typical annual courses with low values around $1 \mu \mathrm{mol} \mathrm{CO} \mathrm{CO}^{-2} \mathrm{~s}^{-1}$ during winter and highest values between 5 and $6 \mu \mathrm{mol} \mathrm{CO} \mathrm{CO}^{-2} \mathrm{~s}^{-1}$ in summer, generally following the annual course of soil temperature (Fig. 3a-c). During summer, soil respiration was severely reduced by low soil moisture in 2004 and 2006, but only gently in 2005. In 2004 the drought occurred late in the growing season, thus soil respiration increased continuously until early August when the highest rates were measured. Thereafter, it quickly dropped with decreasing soil moisture. In 2005 a broad plateau of high soil temperature lasting from end of May to early September combined with 
Table 1 Selected soil properties (mean \pm SD) of 10 soil cores in the main footprint of the CarboEurope eddy covariance tower in the Hainich National Park

\begin{tabular}{|c|c|c|c|c|c|c|c|c|}
\hline $\begin{array}{l}\text { Soil depth } \\
(\mathrm{cm})\end{array}$ & $\begin{array}{l}\text { Stone content } \\
\text { (vol.\%) }\end{array}$ & $\begin{array}{l}\text { Bulk density } \\
\left(\mathrm{g} \mathrm{cm}^{-3}\right)\end{array}$ & $\begin{array}{l}\mathrm{C}_{\mathrm{org}} \\
\left(\mathrm{g} \mathrm{kg}^{-1}\right)\end{array}$ & $\begin{array}{l}\mathrm{C}_{\text {inorg }} \\
\left(\mathrm{g} \mathrm{kg}^{-1}\right)\end{array}$ & $\begin{array}{l}\mathrm{N} \\
\left(\mathrm{g} \mathrm{kg}^{-1}\right)\end{array}$ & $\begin{array}{l}\text { Sand } \\
\left(\mathrm{g} \mathrm{kg}^{-1}\right)\end{array}$ & $\begin{array}{l}\text { Silt } \\
\left(\mathrm{g} \mathrm{kg}^{-1}\right)\end{array}$ & $\begin{array}{l}\text { Clay } \\
\left(\mathrm{g} \mathrm{kg}^{-1}\right)\end{array}$ \\
\hline $0-5$ & $0 \pm 0$ & $0.79 \pm 0.08$ & $64 \pm 17$ & $0.5 \pm 0.4$ & $4.8 \pm 1.0$ & $24 \pm 3$ & $45.9 \pm 80$ & $517 \pm 81$ \\
\hline $5-10$ & $0 \pm 0$ & $0.99 \pm 0.17$ & $42 \pm 14$ & $0.3 \pm 0.3$ & $3.4 \pm 1.0$ & $28 \pm 11$ & $466 \pm 84$ & $506 \pm 86$ \\
\hline $10-20$ & $0.6 \pm 1.2$ & $1.21 \pm 0.12$ & $24 \pm 6$ & $0.2 \pm 0.2$ & $2.2 \pm 0.5$ & $27 \pm 4$ & $473 \pm 99$ & $500 \pm 100$ \\
\hline $20-30$ & $0.2 \pm 0.8$ & $1.31 \pm 0.07$ & $16 \pm 2$ & $0.4 \pm 1.1$ & $1.6 \pm 0.2$ & $29 \pm 10$ & $350 \pm 117$ & $621 \pm 111$ \\
\hline $30-40$ & $2.8 \pm 4.1$ & $1.39 \pm 0.03$ & $11 \pm 3$ & $2.3 \pm 4.0$ & $1.1 \pm 0.2$ & $37 \pm 22$ & $305 \pm 123$ & $658 \pm 124$ \\
\hline $40-50$ & $9.5 \pm 9.0$ & $1.36 \pm 0.11$ & $7.9 \pm 3.6$ & $7.5 \pm 8.7$ & $0.9 \pm 0.3$ & $47 \pm 27$ & $325 \pm 90$ & $628 \pm 82$ \\
\hline $50-60$ & $20.2 \pm 11.8$ & $1.35 \pm 0.15$ & $7.0 \pm 3.8$ & $13 \pm 9$ & $0.8 \pm 0.3$ & $17 \pm 12$ & $279 \pm 124$ & $704 \pm 126$ \\
\hline
\end{tabular}

Fig. 3 Dynamics of soil respiration, soil moisture (8 $\mathrm{cm}$ depth) and soil temperature $(2 \mathrm{~cm}$ depth) and modeled partitioning of soil respiration in the footprint of the Hainich eddy-covariance tower for 2004-2006. Grey symbols denote mean values $( \pm \mathrm{SD})$ of 56 measurement collars in the field, and the different coloured areas show the model output of soil respiration from the three sub-models of the field model. Comparison between modeled and measured values of total soil respiration (TSR) is shown in the small graph at the right

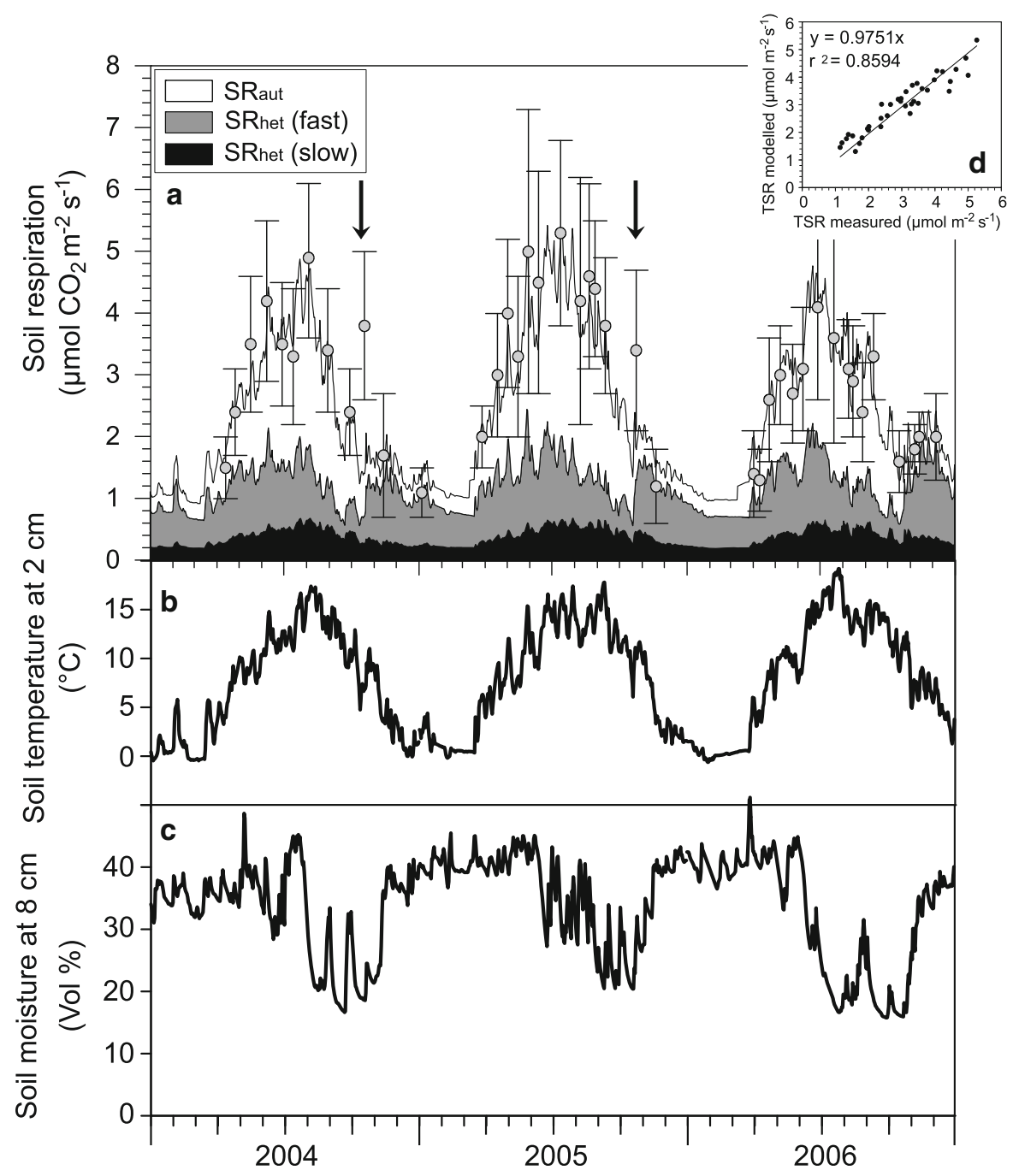


only moderate drought stress resulted in continuous high rates of soil respiration. In 2006, the growing season was characterized by cold temperatures in May and early June followed by a drought. Therefore, soil respiration rates were low in spite of high soil temperatures in July and August.

The field model reflected this pattern quite well except for two values in October 2004 and October 2005 when high respiration of the freshly fallen litter was obviously not captured by the model (Fig. 3a, arrows). Therefore, these values were excluded during model calibration to avoid an over-tuning of the model. After exclusion of these values the modelling resulted in a high correlation between modelled and measured data (Fig. 3d).

Flux partitioning in the model

The output of the field model comprises two heterotrophic fluxes $\left(R_{\text {fast }}\right.$ and $\left.R_{\text {slow }}\right)$, reflecting the mineralisation of carbon from the litter layer and topsoil, respectively, and the autotrophic respiration (Ra, Fig. 3a). The mineralisation of the litter layer $\left(R_{\text {fast }}\right)$ follows soil temperature and moisture but is also strongly influenced by the size of the litter pool that is almost depleted at the end of the growing season, whereas topsoil respiration $\left(R_{\text {slow }}\right)$ with its low decomposition rate constant and large pool size only varies with temperature and moisture. Autotrophic respiration peaked during the growing season, reflecting the close relationship to canopy photosynthesis that has been shown in various recent studies (Tang et al. 2005; Heinemeyer et al. 2006, 2007; Moyano et al. 2007). Higher total soil respiration during summer of 2005 compared to 2004 and 2006 could only partly be explained by high litter input due to high fruit production in 2004 and more favourable soil moisture conditions. Thus, we assumed a higher autotrophic respiration in that year and manipulated the model by increasing fineroot biomass during the summer months of 2005 (see arrow 'B' in Fig. 2). This can be justified by the fact that the GPP calculated from eddy covariance data was highest in 2005 (Fig. 4a). The model output for the total 8 years of model application shows this property of the modular soil respiration model: autotrophic respiration was strongly coupled to canopy photosynthesis (GPP from eddy covariance; Fig. 4a). It is also noteworthy that the model calculations resulted in a strong correlation between annual sum of heterotrophic respiration and the litter production of the previous year (Fig. 4b). Only in the very dry year 2003 this correlation was broken. This shows that the model reflects important properties of the soil system.

Incubation and extrapolated mineralisation rates

$\mathrm{C}$ mineralisation rate $\left(\mathrm{mg} \mathrm{C} \mathrm{g}^{-1} \mathrm{C} \mathrm{day}^{-1}\right)$ at the same temperature $\left(15^{\circ} \mathrm{C}\right)$ and moisture $(60 \%$ WHC) was much higher in the litter layer than in the other soil layers, and the mineralisation rate decreased with increasing depth (Fig. 5a, b shows the mineral soil layers in detail). The differences between the two experiments (FORCAST 2000 and CarboEurope 2004) were small. The initial respiration rates during the FORCAST incubation were generally 10-20\% higher, but decreased with time (Fig. 5). The CarboEurope incubation samples were stored for some time after sieving, thus, we presume that the initially occurring increase of respiration after disturbance was not measured. To extrapolate the laboratory data
Fig. 4 Inter-annual variations of the modeled autotrophic respiration related to the net carbon assimilation of the canopy (NCA, left site) and of the modeled heterotrophic respiration related to the litter production of the previous year
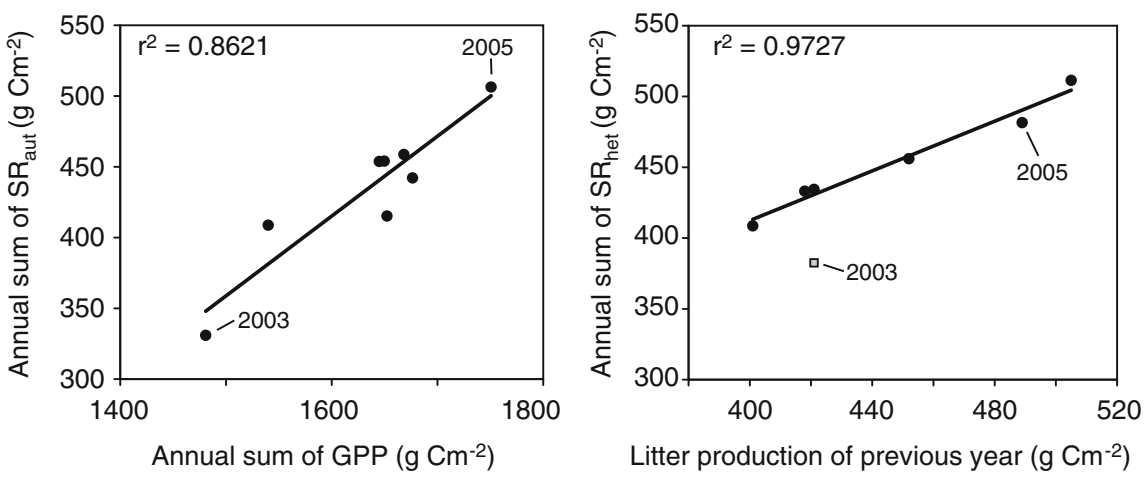

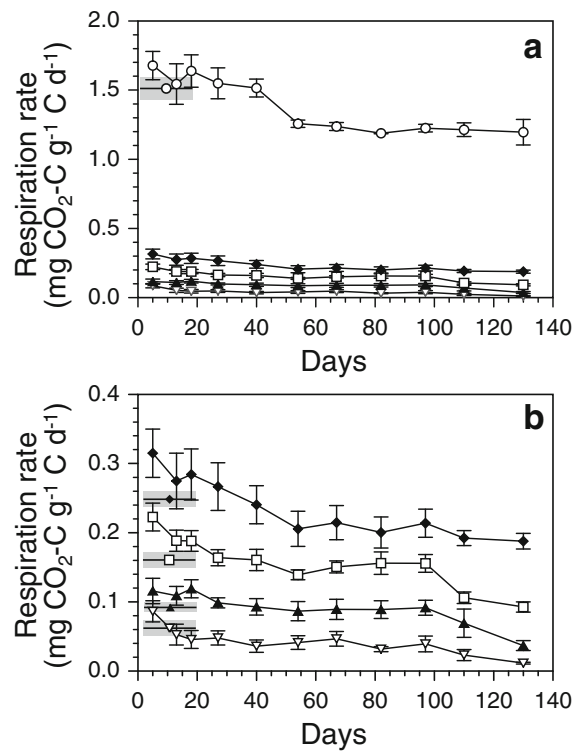

FORCAST sampling in 2000

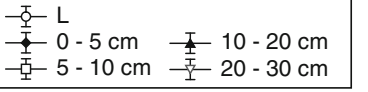

CarboEurope sampling in 2004

\section{$\multimap-\mathrm{L}$}

$\because 0-5 \mathrm{~cm} \Longrightarrow 10-20 \mathrm{~cm}$ $\rightarrow-5-10 \mathrm{~cm} \rightarrow-20-30 \mathrm{~cm}$

Fig. 5 Mean $\mathrm{CO}_{2}-\mathrm{C}$ evolution rates (per g $\mathrm{C}$ and day) for litter and mineral soil layers from Hainich $2000(n=4)$ and $2004(n=10)$ during laboratory incubation at $15^{\circ} \mathrm{C}$. Intervals and grey areas indicate SE. b is an enlargement of (a)

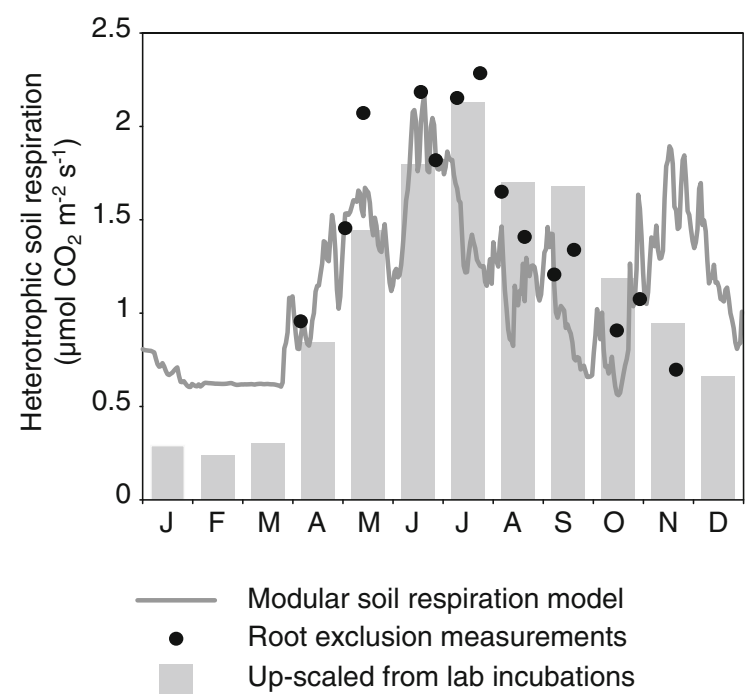

Fig. 6 Comparison between the two modelling approaches [field model (line) and lab model (bars)] and field-measured values of heterotrophic soil respiration (dots) in 2006. Measured rates are mean values of single measurements from 25 collars with $1 \mu \mathrm{m}$ mesh to the field, the rates used for up-scaling were based on the CarboEurope sampling in 2004.

Comparison of the different approaches

For 2006, the heterotrophic respiration from the two modeling approaches was compared to results of the meshbag experiment conducted in the Hainich forest (Moyano et al. 2008, Fig. 6). Generally, the two models show good accordance with the mean fluxes from the bags with $1 \mu \mathrm{m}$ mesh size. However, in some situations the different approaches deviate strongly from each others: (i) during winter the modular soil respiration model gave higher rates of mineralisation than the upscaled lab incubations, (ii) during the dry period in July the modular soil respiration model responded more sensitively to soil moisture deficit, and (iii) increased fluxes due to high availability of easily decomposable substrate after litterfall were calculated by the modular soil respiration model but not by the up-scaled lab incubations. The meshbag measurements showed only a small increase at the end of October (Fig. 6).

Integration of estimated fluxes

Soil carbon balances were estimated for the years 2000-2007 with the field-calibrated modular soil respiration model (Table 2) and for the years 20022006 with the lab-calibrated model (Table 3). Litter input varied between 401 and $483 \mathrm{~g} \mathrm{C} \mathrm{m}^{-2}$ year $^{-1}$ mainly due to high fruit production in the years 2002 , 2004 , and 2006. The average annual amount of carbon input into the soil was $441 \mathrm{~g} \mathrm{C} \mathrm{m}^{-2}$ year $^{-1}$ for the period 2000-2007 and $452 \mathrm{~g} \mathrm{C} \mathrm{m}^{-2}$ year $^{-1}$ for 20022006. Interannual variation of heterotrophic respiration was in the same range (385-497 $\mathrm{g} \mathrm{C} \mathrm{m}^{-2}$ year $^{-1}$ ) resulting in an 8-years average of $440 \mathrm{~g} \mathrm{C} \mathrm{m}^{-2}$ year ${ }^{-1}$. On average the soil is almost balanced accumulating only $1 \mathrm{~g} \mathrm{C} \mathrm{m}^{-2}$ year $^{-1}$ when considering the years 2000-2007 and $16 \mathrm{~g} \mathrm{C} \mathrm{m}^{-2}$ year $^{-1}$ when considering only the years 2002-2006, respectively. The latter value was calculated to compare the results to the lab-calibrated model that only could be run for this smaller period. The lab-calibrated model resulted in a mean annual rate of heterotrophic respiration of $417 \mathrm{~g} \mathrm{C} \mathrm{m}^{-2}$ year $^{-1}$ and a soil carbon accumulation of $35 \mathrm{~g} \mathrm{C} \mathrm{m}^{-2}$ year $^{-1}$. 
Table 2 Litter input (leaves, bud scales, fruits, ground vegetation, roots $<2 \mathrm{~mm}$ ), heterotrophic soil respiration, autotrophic respiration, total soil respiration and soil carbon balance as calculated based on field experiments

\begin{tabular}{lllllr}
\hline Year & $\begin{array}{l}\text { Litter input } \\
\left(\mathrm{g} \mathrm{C} \mathrm{m}^{-2} \text { year }^{-1}\right)\end{array}$ & $\begin{array}{l}\mathrm{R}_{\mathrm{ht}} \\
\left(\mathrm{g} \mathrm{C} \mathrm{m}^{-2} \mathrm{year}^{-1}\right)\end{array}$ & $\begin{array}{l}R_{\text {aut }} \\
\left(\mathrm{g} \mathrm{C} \mathrm{m}^{-2} \mathrm{year}^{-1}\right)\end{array}$ & $\begin{array}{l}\text { Total soil respiration } \\
\left(\mathrm{g} \mathrm{C} \mathrm{m}^{-2} \text { year }^{-1}\right)\end{array}$ & $\begin{array}{l}\text { Soil C balance } \\
\left(\mathrm{g} \mathrm{C} \mathrm{m}^{-2} \mathrm{year}^{-1}\right)\end{array}$ \\
\hline 2000 & 401 & 432 & 482 & 914 & -31 \\
2001 & 411 & 408 & 442 & 850 & 3 \\
2002 & 426 & 430 & 459 & 889 & -4 \\
2003 & 427 & 385 & 331 & 716 & 42 \\
2004 & 473 & 437 & 409 & 846 & 36 \\
2005 & 453 & 474 & 506 & 980 & -21 \\
2006 & 483 & 454 & 415 & 869 & 29 \\
2007 & 451 & 497 & 454 & 951 & -46 \\
Mean & 441 & 442 & 437 & 876 & $1(16)^{\mathrm{a}}$ \\
\hline
\end{tabular}

${ }^{\mathrm{a}}(2002-2006)$

Table 3 Litter input, heterotrophic soil respiration and soil carbon balance as calculated based on the laboratory incubation experiment

\begin{tabular}{lllc}
\hline Year & $\begin{array}{l}\text { Litter input } \\
\left(\mathrm{g} \mathrm{C} \mathrm{m}^{-2} \mathrm{year}^{-1}\right)\end{array}$ & $\begin{array}{l}R_{\text {het }} \\
\left(\mathrm{g} \mathrm{C} \mathrm{m}^{-2} \text { year }^{-1}\right)\end{array}$ & $\begin{array}{l}\text { Soil C balance } \\
\left(\mathrm{g} \mathrm{C} \mathrm{m}^{-2} \text { year }^{-1}\right)\end{array}$ \\
\hline 2002 & 426 & 437 & -11 \\
2003 & 427 & 395 & 32 \\
2004 & 473 & 395 & 78 \\
2005 & 453 & 443 & 10 \\
2006 & 483 & 417 & 66 \\
Mean & 452 & 417 & 35 \\
\hline
\end{tabular}

Comparison to nighttime eddy covariance measurements

Finally, the half-hourly results of the modular soil respiration model were compared to original eddy covariance values measured during nighttime, and to results of the gap-filling procedure by the CarboEurope database (so called Level 4 data). For the comparison with original eddy covariance data, nighttime datasets of the years 2004-2006 were split into sub-sets at stable and neutral stratification and binned into $u^{*}$ classes (Fig. 7). This comparison shows a clear dependency on friction velocity and atmospheric stratification. At stable stratification and higher $u^{*}$ values, the soil respiration was about 0.5-1 $\mu \mathrm{mol} \mathrm{CO}_{2} \mathrm{~m}^{-2} \mathrm{~s}^{-1}$ lower than the nighttime fluxes. This accounted for $70-80 \%$ of the ecosystem respiration. At conditions near to neutral stratification the picture was different. The eddy covariance seemed not to be affected so strongly by friction velocity but year to year differences were strong. In 2004 and 2006 the ecosystem respiration was slightly higher than the up-scaled soil respiration, whilst in 2005 mean soil respiration exceeded mean ecosystem respiration by about $0.5 \mu \mathrm{mol} \mathrm{CO} \mathrm{CO}^{-2} \mathrm{~s}^{-1}$. In addition, data from six consecutive nights in August 2005 were shown in Fig. 8. While some of the eddy covariance data exceeded the modelled soil respiration by $1-1.5 \mu \mathrm{mol} \mathrm{CO} \mathrm{CO}^{-2} \mathrm{~s}^{-1}$, most of the eddy covariance values scattered around lower values.

\section{Discussion}

Soil carbon balance in the Hainich old-growth forest

Our results indicate that the annual balances vary around zero, and, on average, only $1-35 \mathrm{~g} \mathrm{C} \mathrm{m}^{-2}$ year $^{-1}$ are stored, depending on approach and averaging period. 
Fig. 7 Differences between nighttime fluxes of eddy covariance (TER, total ecosystem respiration) and modeled soil respiration data (SR, from field model) plotted against friction velocity $\left(u^{*}\right)$ for stable and neutral stratification during the growing seasons 20042006. Data were binned into $u^{*}$ classes with $0.05 \mathrm{~m} \mathrm{~s}^{-1}$ intervals
Period with fully developed canopy (15.5. - 30.9.)
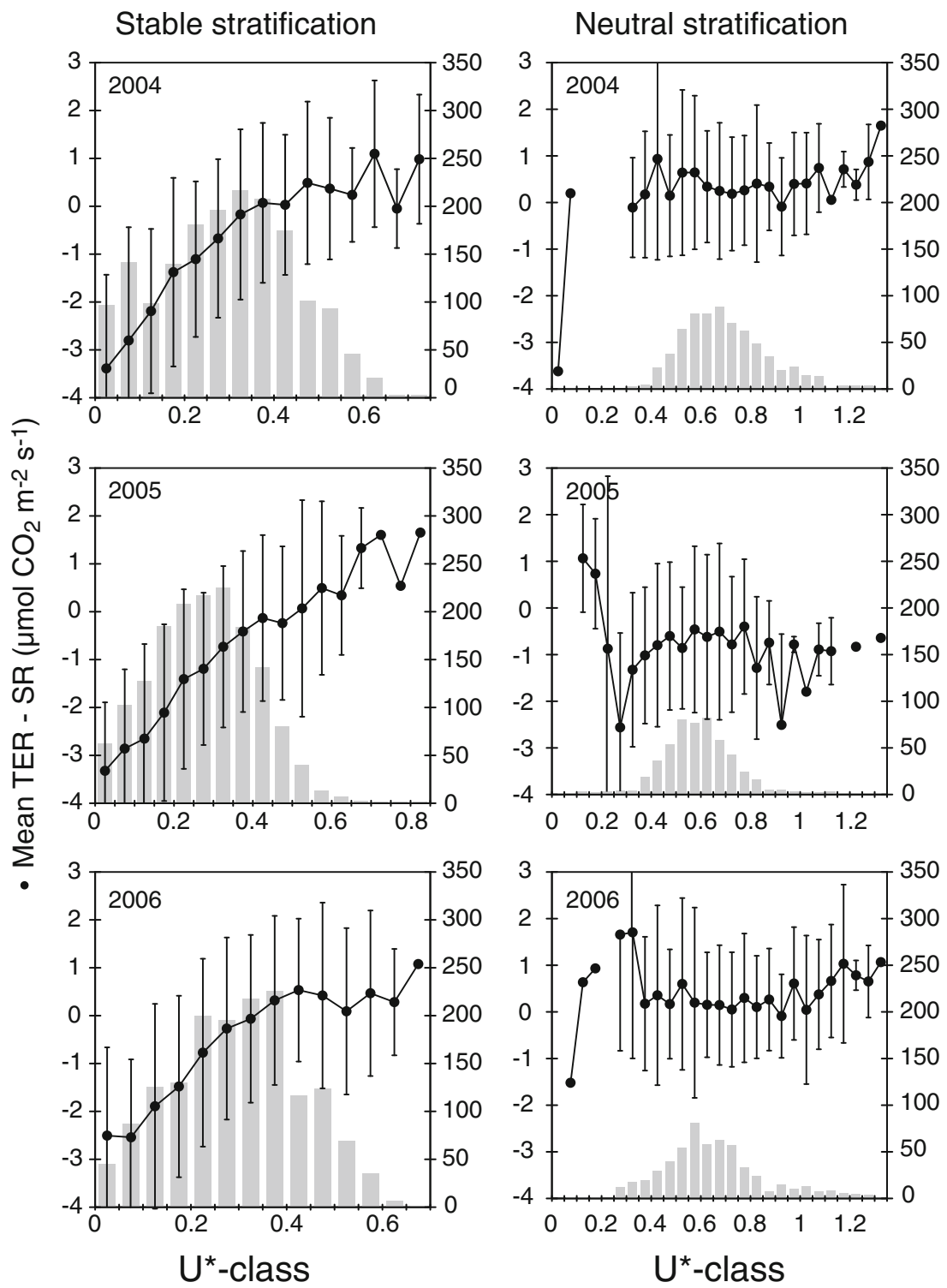

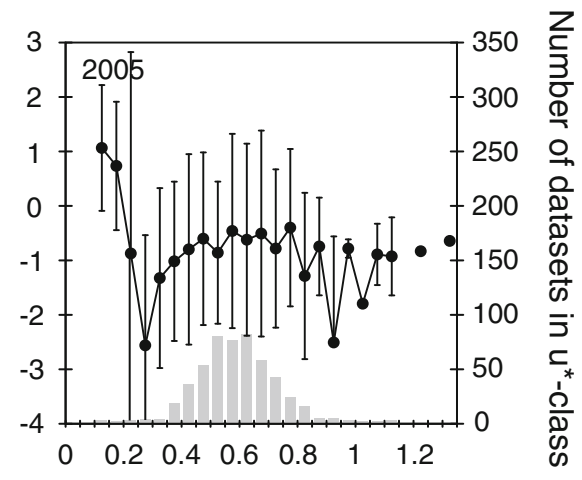

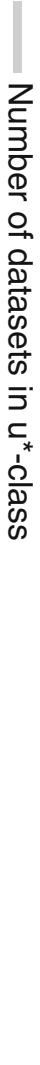

The fact that small amounts of leached DOC were not considered may move Hainich forest even closer to equilibrium. This is in accordance with results from an integrative study by Pregitzer and Euskirchen (2004) who gave a value around $9 \mathrm{~g} \mathrm{C} \mathrm{m}^{-2}$ year $^{-1}$ as average storage in temperate forests including the highest age classes and with a study by Gaudinski et al. (2000), who calculated $10-30 \mathrm{~g} \mathrm{C} \mathrm{m}^{-2}$ year $^{-1}$ for a close-to-equilibrium forest by means of isotopic studies. Also Griffiths and Swanson (2001) observed only small increases of carbon stocks between middle-aged and old-growth forests. Studies by repeated stocktaking that suggest higher sequestration rates (Kelly and Mays 2005; Gleixner et al. 2009) have severe limitations since small Puerkhauer augers were used where carryover of soil material within the auger during sampling is possible and bulk density was not determined at the same samples.

The low sequestration rate found in this study is in accordance with general ecological theory: Agren and Bosatta (1987) predicted with a cohort model of continuous litter input that carbon in old-growth 


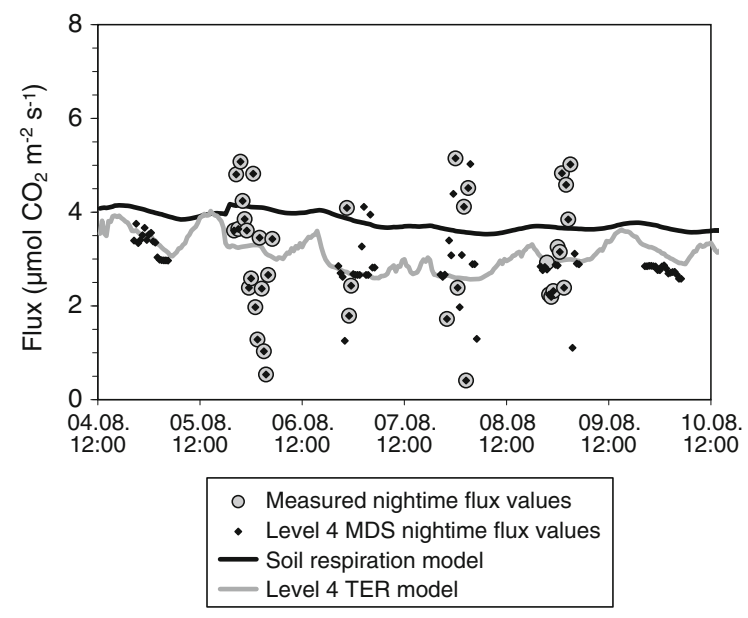

Fig. 8 Soil respiration (field model) and ecosystem respiration data for six nights in August 2005. Big circles represent the originally measured eddy data, black diamonds the gap-filled data. The grey line represents the ecosystem respiration model that is used for flux partitioning and calculation of GPP

forest soil is at steady state, which means either constant or linearly increasing amounts of soil carbon. Predicted increases of soil carbon are small and only occur in situations that are unfavourable for microbial biomass. Thus, old-growth forest soils in general should be neither sinks nor sources of carbon in a long-term perspective. However, in a more recent study Ågren et al. (2008) state that forest soils in Sweden are far from equilibrium due to recent disturbances that increased litter production during the past decades (increase of atmospheric $\mathrm{CO}_{2}$, nitrogen deposition). The average rates of increase they report (12-13 $\mathrm{g} \mathrm{C} \mathrm{m}^{-2}$ year $^{-1}$ ) are in the same order of magnitude as our results. Thus, Hainich forest soil may also be considered as non-equilibrium sequestering small amounts of carbon in stabilized soil organic matter.

\section{Methods comparison}

The results of the three different methods for the year 2006 as compiled in Fig. 6 show good accordance in most situations (particularly in spring and early summer when all approaches coincide with maximum heterotrophic respiration rates around $2 \mu \mathrm{mol} \mathrm{CO} \mathrm{CO}^{-2} \mathrm{~s}^{-1}$ ) but also show differences that characterize the individual properties of each approach.

The year 2006 was characterized by a dry period in July, some rainfall at cool temperatures in August and another dry period lasting from beginning of September until end of October. In addition, November temperatures were extraordinarily high. The decrease in soil moisture in July caused a drop in heterotrophic soil respiration calculated by the field model that was not seen for the other approaches which stay at highest level during July.

For the root exclusion approach, this may result from the fact that the desiccation of the soil inside the bag was delayed since roots were excluded and did not take up water from that soil. This interpretation is supported by the fact that at undisturbed plots total soil respiration decreased during that period (see Fig. 3). The high rates in the up-scaled incubation values seemed to be the consequence of a higher $Q_{10}$-value obtained from the lab incubations that overruled the influence of soil moisture function. A general problem of modeling the soil water response is that soil moisture is measured in the top-soil but not in the litter which has the highest dynamics of water content.

During the months of August-October the rates decreased continuously in all approaches. The slightly higher rates obtained from the root exclusion measurements and the lab model when compared to the field model rates seem to be reasonable even though they might have different reasons: the root exclusion plots might still have higher soil moisture, whereas the up-scaling of the lab incubations did not consider a depletion of the litter pool during summer. This is also the reason for the deviation between field model and lab-incubations model during the winter months (November-March). The field model rate increased severely in November due to the high input of freshly fallen litter into the fast decomposable pool and was higher during the whole winter period. Since the lab incubations were only done once and, therefore, remained a snapshot of a system that is highly dynamic in pool size as well as decomposition rate (Dilly and Munch 1996; Cotrufo et al. 2000; Norby et al. 2001; Rubino et al. 2007).

However, also the rates in the root exclusion experiment were very low during November. This might result from a lower litter input into the experimental plots, a missing priming effect of freshly fallen litter on rhizosphere bacteria, or might indicate a wrong partitioning within the field model favouring unrealistically the heterotrophic over the autotrophic part. 
Overall, the root exclusion experiment and the incubations in the laboratory confirm the soil respiration partition as conducted in the field model and support the rate constants as well as temperature and moisture response functions that were chosen, even if some limitations of the method may cause larger deviations in certain situations. These deviations show that further research has to be on certain problems to increase the quality of all approaches:

1. Laboratory incubations should be conducted several times during the year to account for seasonal dynamics of litter pools as well as litter quality. In addition, the treatment of the samples may result in an increased respiration rate due to aeration and exposition of new surfaces (Persson et al. 2000). On the other hand the supply of the soil microbial biomass with easily decomposable carbon compounds by the roots and the mycorrhiza is interrupted and priming is suppressed. However, detailed studies with disturbed and undisturbed soils (Hassink 1992; Persson et al. 2000) led to the conclusion that sieving does not result in unnatural disturbance and, therefore, the rates as well as the temperature and moisture response functions obtained by incubations in the laboratory can principally be extrapolated to the field.

2. Root exclusion techniques (Heinemeyer et al. 2006, 2007; Subke et al. 2006; Moyano et al. 2007, 2008; Epron 2009) reveal important insights, but root decomposition, disturbance of the soil structure, lateral diffusion of $\mathrm{CO}_{2}$ (Jassal and Black 2006), and differences in soil water content between treatments may cause the proportion of $\mathrm{Rh}$ to be overestimated. Thus, root exclusion experiments should be thoroughly checked for soil moisture in particular during dry periods and, where appropriate, corrected for soil moisture differences to the control.

3. Modular models for soil respiration like the one by Kutsch and Kappen (1997) we used in that study need a lot of detailed information to run the single modules. However, even with a high amount of information on litter production, carbon pool sizes and photosynthetic production, the model has various solutions that correlate with the field measured total soil respiration. Therefore, additional information from other approaches is highly needed to improve the quality of these models.

4. Soil respiration measurements in the field have been considered to be reliable (Davidson et al. 2002; Pumpanen et al. 2004), but the spatial representation of the collars is a critical factor (Subke et al. 2003, 2006).

5. Finally, it is important to note that also the detection of carbon input into the soil is highly uncertain. Particularly, methods to estimate belowground carbon input should be further developed.

Given the differences in details, the fact that the different approaches resulted in a high accordance of the annual mineralisation rates may be surprising but increases the confidence in these annual balances, since the different methodological approaches can be understood as a cross check.

Comparison between chamber measured soil fluxes and eddy derived ecosystem respiration

Knohl et al. (2003) found high amounts of carbon fixed in the Hainich by means of eddy covariance measurements $\left(\sim 500 \mathrm{~g} \mathrm{C} \mathrm{m}^{-2}\right.$ year $\left.^{-1}\right)$. However, these results have been challenged by Kutsch et al. (2008) who found that the eddy covariance measurements at this site were severely biased by advection. High carbon sequestration in the forest biomass could not be confirmed by repeated forest inventory measurements (Mund et al. pers. comm.). Thus, the soil carbon balance is needed to confirm if the system is accumulating the high amounts of carbon calculated from eddy covariance or not. Our results support the 'advection hypothesis' by Kutsch et al. (2008), since the difference between $\mathrm{C}$ input and heterotrophic respiration indicates that only a small amount of carbon (1-35 $\mathrm{g} \mathrm{C} \mathrm{m}^{-2}$ year $^{-1}$ ) is sequestered by the soil. However, also a direct comparison between soil respiration and nighttime fluxes derived by eddy covariance reveals interesting insights:

A comparison between up-scaled fluxes from soil chamber measurements and the nighttime fluxes from eddy-covariance should ideally result in lower values for soil respiration since it is only a fraction of total ecosystem respiration measured by eddy covariance (Aubinet et al. 2005). However, nighttime fluxes from tower measurements underlie a number of systematic 
errors that still are not fully understood and undermine the confidence in eddy covariance measurements (Aubinet 2008; Finnigan 2008). In 2004 and 2006 the ecosystem respiration was slightly higher than the upscaled soil respiration, whilst in 2005 mean soil respiration exceeded mean ecosystem respiration by about $0.5 \mu \mathrm{mol} \mathrm{CO} \mathrm{CO}_{2} \mathrm{~m}^{-2} \mathrm{~s}^{-1}$. This can either result from a bias in the soil respiration measurements during that year that led to a wrong calibration of the model, or to an increased abundance of advection that biased the eddy covariance measurements.

A closer look at some diurnal courses during August 2005 when the discrepancy between eddy measurements and chamber model was highest shows that some of the eddy covariance data did exceed the modelled soil respiration by $1-1.5 \mu \mathrm{mol} \mathrm{CO} \mathrm{CO}_{2} \mathrm{~m}^{-2} \mathrm{~s}^{-1}$, but most of the eddy covariance values scattered around lower values. A pattern like this was also found by van Gorsel et al. (2007) who stated that the highest values should be taken as the more confident ones while the lower should be rejected as probably affected by advection or other systematic errors. This challenges the common filtering and gap-filling philosophies (Reichstein et al. 2005; Moffat et al. 2007) that define the scatter completely as random error and therefore result in the depicted lower values. When unidentified or simply ignored systematic errors (e.g. resulting from advection) are treated as random errors they are multiplied during standard gap-filling procedures or result in wrong model parameterization (Lasslop et al. 2008). Even if the uncertainties of chamber measurements as discussed above are taken into consideration, we conclude that the standard filtering and gap-filling procedures provided up to now have not resulted in a satisfying reconciliation of eddy covariance and chamber measurements for this site. Obviously, too many efforts have been put into gap-filling procedures but not enough into proper filter methods. We doubt that standard filtering results in unbiased data sets with only random errors for all sites. Future methodological developments of eddy covariance should focus on the uniqueness of single site errors rather than further standardization.

\section{Conclusion}

The determination of short-term soil C stock changes remains a difficult and laborious job. Due to the high spatial variability, direct measurements of $\mathrm{C}$ stock changes are only possible after several years with a reasonable number of samples. Indirect methods determining $\mathrm{C}$ stock changes as difference between $\mathrm{C}$ input (above-and belowground litter) and output (heterotrophic respiration) are all associated with a high uncertainty and can be biased. We increased confidence in determined fluxes by comparing independent methods. While all applied methods to determine heterotrophic respiration tend to over- or underestimate fluxes during some climatic conditions, they seem to be balanced on the long run since all methods result in rather similar annual fluxes.

Acknowledgements This study is part of the project CarboEurope-IP supported by the European Commission, Directorate-General Research, Sixth Framework Programme, Priority 1.1.6.3: Global Change and Ecosystem, Contract No. GOCE-CT-2003-505572. We especially thank the administration of the National Park Hainich for the possibility to conduct our research at this site and for co-operation. Many thanks go also to our field crew (Waldemar Ziegler, Katarina Metzger, Nadine Hempel, Marco Pöhlmann) for their efforts in the field and various lab crews in Germany and Sweden for their efforts in the lab and two anonymous reviewers for their helpful comments.

Open Access This article is distributed under the terms of the Creative Commons Attribution Noncommercial License which permits any noncommercial use, distribution, and reproduction in any medium, provided the original author(s) and source are credited.

\section{References}

Ågren GI, Bosatta E (1987) Theoretical analysis of the longterm dynamics of carbon and nitrogen in soils. Ecology 68:1181-1189

Ågren GI, Hyvonen R, Nilsson T (2008) Are Swedish forest soils sinks or sources for $\mathrm{CO}_{2}-$ model analyses based on forest inventory data. Biogeochemistry 89:139-149 (reprinted)

Anthoni P, Knohl A, Rebmann C, Freibauer A, Mund M, Ziegler W, Kolle O, Schulze ED (2004) Forest and agricultural land-use-dependent $\mathrm{CO}_{2}$ exchange in Thuringia, Germany. Glob Chang Biol 10:2005-2019

Aubinet M (2008) Eddy covariance $\mathrm{CO}_{2}$ flux measurements in nocturnal conditions: an analysis of the problem. Ecol Appl 18:1368-1378

Aubinet M, Grelle A, Ibrom A, Rannik Ü, Moncrieff J, Foken T, Kowalski A, Martin P, Berbigier P, Bernhofer C, Clement R, Elbers J, Granier A, Grünwald T, Morgenstern K, Pilegaard K, Rebmann C, Snijders W, Valentini R, Vesala T (2000) Estimates of the annual net carbon and 
water exchange of forests: the EUROFLUX methodology. Adv Ecol Res 30:113-175

Aubinet M, Berbigier P, Bernhofer $\mathrm{CH}$, Cescatti A, Feigenwinter C, Granier A, Grünwald TH, Havrankova K, Heinesch B, Longdoz B, Marcolla B, Montagnani L, Sedlak P (2005) Comparing $\mathrm{CO}_{2}$ storage and advection conditions at night at different carboeuroflux sites. Boundary-Layer Meteorol 116:63-94

Claus A, George E (2005) Effect of stand age on fine-root biomass and biomass distribution in three European forest chronosequences. Can J For Res 35:1617-1625

Cotrufo F (2003) FORCAST (Forest carbon-nitrogen trajectories) database. http://www.dow.wau.nl/natcons/NP/FOR CAST/files_database_forcast $2 . h t m l$

Cotrufo MF, Miller M, Zeller B (2000) Litter decomposition. In: Schulze ED (ed) Carbon and nitrogen cycling in European forest ecosystems. Ecological studies, vol 142. Springer, Berlin, pp 276-296

Davidson EA, Savage K, Verchot LV, Navarro R (2002) Minimizing artifacts and biases in chamber-based measurements of soil respiration. Agric For Meteorol 113: 21-37

Davidson EA, Janssens IA, Luo YQ (2006) On the variability of respiration in terrestrial ecosystems: moving beyond $\mathrm{Q}_{10}$. Glob Chang Biol 12:154-164

Desjardins RL, Lemon ER (1974) Limitations of an eddycorrelation technique for the determination of the carbon dioxide and sensible heat fluxes. Boundary-Layer Meteorol 5:475-488

Dilly O, Munch JC (1996) Microbial Biomass content. basal respiration and enzyme activities during the course of decomposition of leaf litter in a Black Alder (Alnus glutinosa (L.) Gaertn.) forest. Soil Biol Biochem 28: 1073-1081

Epron D (2009) Separating autotrophic and heterotrophic components of soil respiration: lessons learned from trenching and related root exclusion experiments. In: Kutsch WL, Bahn M, Heinemeyer A (eds) Soil carbon dynamics - an integrated methodology. Cambridge University Press, Cambridge, pp 157-168

Finnigan J (2008) An introduction to flux measurements in difficult conditions. Ecol Appl 18:1340-1350

Gaudinski JB, Trumbore SE, Davidson EA, Zheng SH (2000) Soil carbon cycling in a temperate forest: radiocarbonbased estimates of residence times, sequestration rates and partitioning of fluxes. Biogeochemistry 51:33-69

Gleixner G, Tefs C, Jordan A, Hammer M, Wirth C, Nueske A, Telz A, Schmidt UE, Glatzel S (2009) Soil carbon accumulation in old-growth forests. In: Wirth C, Gleixner G, Heimann $M$ (eds) Old-growth forests; function, fate and value. Ecological studies. Springer, Heidelberg, pp 231-266

Griffiths RP, Swanson AK (2001) Forest soil characteristics in a chronosequence of harvested Douglas-fir forests. Can J For Res 31:1871-1879

Hassink J (1992) Effects of soil texture and structure on carbon and nitrogen mineralization in grassland soils. Biol Fertil Soils 14:126-134

Heinemeyer A, Ineson P, Ostle N, Fitter AH (2006) Respiration of the external mycelium in the arbuscular mycorrhizal symbiosis shows strong dependence on recent photosynthates and acclimation to temperature. New Phytol 171:159-170

Heinemeyer A, Hartley IP, Evans SP, De la Fuente JAC, Ineson P (2007) Forest soil $\mathrm{CO}_{2}$ flux: uncovering the contribution and environmental responses of ectomycorrhizas. Glob Chang Biol 13:1786-1797

Högberg P, Nordgren A, Buchmann N, Taylor AFS, Ekblad A, Hogberg MN, Nyberg G, Ottosson-Lofvenius M, Read DJ (2001) Large-scale forest girdling shows that current photosynthesis drives soil respiration. Nature 411:789-792

Hyvönen R, Ågren GI, Linder S, Persson T, Cotrufo MF, Ekblad A, Freeman M, Grelle A, Janssens IA, Jarvis PG, Kellomaki S, Lindroth A, Loustau D, Lundmark T, Norby RJ, Oren R, Pilegaard K, Ryan MG, Sigurdsson BD, Stromgren M, van Oijen M, Wallin G (2007) The likely impact of elevated $\left[\mathrm{CO}_{2}\right]$, nitrogen deposition, increased temperature and management on carbon sequestration in temperate and boreal forest ecosystems: a literature review. New Phytol 173:463-480

Jassal RS, Black TA (2006) Estimating heterotrophic and autotrophic soil respiration using small-area trenched plot technique: theory and practice. Agric For Meteorol 140: 193-202

Kelly JM, Mays PA (2005) Soil carbon changes after 26 years in a Cumberland Plateau hardwood forest. Soil Sci Soc Am J 69:691-694

Knohl A, Schulze ED, Kolle O, Buchmann N (2003) Large carbon uptake by an unmanaged 250 -year-old deciduous forest in Central Germany. Agric For Meteorol 118: 151-167

Knohl A, Søe ARB, Kutsch WL, Göckede M, Buchmann N (2008) Representative estimates of soil and ecosystem respiration in an old beech forest. Plant Soil 302:189-202

Kögel-Knabner I, Ekschmitt K, Flessa H, Guggenberger G, Matzner E, Marschner B, von Luetzow M (2008) An integrative approach of organic matter stabilization in temperate soils: linking chemistry, physics, and biology. J Plant Nutr Soil Sci 171:5-13

Kolle O, Rebmann C (2007) Eddysoft-documentation of a software package to acquire and process eddy-covariance data. Technical reports. Max-Planck-Institute for Biogeochemistry, Jena

Kutsch WL, Kappen L (1997) Aspects of carbon and nitrogen cycling in soils of the Bornhoved lake district. 2. Modelling the influence of temperature increase on soil respiration and organic carbon content in arable soils under different managements. Biogeochemistry 39:207-224

Kutsch WL, Staack A, Wötzel J, Middelhoff U, Kappen L (2001) Field measurements of root respiration and total soil respiration in an alder forest. New Phytol 150:157-168

Kutsch WL, Kolle O, Rebmann C, Knohl A, Ziegler W, Schulze $\mathrm{ED}$ (2008) Advection and resulting $\mathrm{CO}_{2}$ exchange uncertainty in a tall forest in central Germany. Ecol Appl 18: 1391-1405

Kutsch WL, Bahn M, Heinemeyer A (2009a) Soil carbon relations-an overview. In: Kutsch WL, Bahn M, Heinemeyer A (eds) Soil carbon dynamics - an integrated methodology. Cambridge University Press, Cambridge, pp 1-15

Kutsch WL, Schimel J, Denef K (2009b) Measuring soil microbial parameters relevant for soil carbon fluxes. In: 
Kutsch WL, Bahn M, Heinemeyer A (eds) Soil carbon dynamics - an integrated methodology. Cambridge University Press, Cambridge, pp 169-186

Lasslop G, Reichstein M, Kattge J, Papale D (2008) Influences of observation errors in eddy flux data on inverse model parameter estimation. Biogeosciences 5:1311-1324

Moffat AM, Papale D, Reichstein M, Hollinger DY, Richardson AD, Barr AG, Beckstein C, Braswell BH, Churkina G, Desai AR, Falge E, Gove JH, Heimann M, Hui DF, Jarvis AJ, Kattge J, Noormets A, Stauch VJ (2007) Comprehensive comparison of gap-filling techniques for eddy covariance net carbon fluxes. Agric For Meteorol 147: 209-232

Moncrieff JB, Massheder JM, de Bruin H, Elbers J, Friborg T, Heusinkveld B, Kabat P, Scott S, Soegaard H, Verhoef A (1997) A system to measure surface fluxes of momentum, sensible heat, water vapour and carbon dioxide. J Hydrol 188-189:589-611

Moyano FE, Kutsch WL, Schulze ED (2007) Response of mycorrhizal, rhizosphere and soil basal respiration to temperature and photosynthesis in a barley field. Soil Biol Biochem 39:843-853

Moyano FE, Kutsch WL, Rebmann C (2008) Soil respiration fluxes in relation to photosynthetic activity in broad-leaf and needle-leaf forest stands. Agric For Meteorol 148: 135-143

Moyano FE, Atkin OK, Bahn M, Bruhn D, Burton AJ, Heinemeyer A, Kutsch WL, Wieser G (2009) Respiration from roots and the mycorrhizosphere. In: Kutsch WL, Bahn M, Heinemeyer A (eds) Soil carbon dynamics-an integrated methodology. Cambridge University Press, Cambridge, pp 127-156

Mund M (2004) Carbon pools of European beech forests (Fagus sylvatica) under different silvicultural management. Berichte des Forschungszentrums Waldökosysteme, Göttingen, p 256

Norby RJ, Cotrufo MF, Ineson P, O’Neill EG, Canadell JG (2001) Elevated $\mathrm{CO}_{2}$, litter chemistry, and decomposition: a synthesis. Oecologia 127:153-165

Oberdorfer E (1994) Pflanzensoziologische Exkursionsflora. Verlag Eugen Ulmer, München

Persson T (1989) Role of soil animals in C and N mineralisation. Plant Soil 115:241-245

Persson T, Karlsson PS, Seyferth U, Sjöberg RM, Rudebeck A (2000) Carbon mineralisation in European forest soils. In: Schulze ED (ed) Carbon and nitrogen cycling in European forest ecosystems. Ecological studies, vol 142. Springer, New York, pp 257-275

Pregitzer KS, Euskirchen ES (2004) Carbon cycling and storage in world forests: biome patterns related to forest age. Glob Chang Biol 10:2052-2077

Pumpanen J, Kolari P, Ilvesniemi H, Minkkinen K, Vesala T, Niinisto S, Lohila A, Larmola T, Morero M, Pihlatie M, Janssens I, Yuste JC, Grunzweig JM, Reth S, Subke JA, Savage K, Kutsch W, Ostreng G, Ziegler W, Anthoni P, Lindroth A, Hari P (2004) Comparison of different chamber techniques for measuring soil $\mathrm{CO}_{2}$ efflux. Agric For Meteorol 123:159-176

Reichstein M, Falge E, Baldocchi D, Papale D, Aubinet M, Berbigier P, Bernhofer C, Buchmann N, Gilmanov T, Granier A, Grunwald T, Havrankova K, Ilvesniemi H, Janous D, Knohl A, Laurila T, Lohila A, Loustau D, Matteucci G, Meyers T, Miglietta F, Ourcival JM, Pumpanen J, Rambal S, Rotenberg E (2005) On the separation of net ecosystem exchange into assimilation and ecosystem respiration: review and improved algorithm. Glob Chang Biol 11:1424-1439

Rubino M, Lubritto C, D’Onofrio A, Terrasi F, Gleixner G, Cotrufo MF (2007) An isotopic method for testing the influence of leaf litter quality on carbon fluxes during decomposition. Oecologia 154:155-166

Schrumpf M, Schumacher J, Schöning I, Schulze ED (2008) Monitoring carbon stock changes in European soils: process understanding and sampling strategies. In: Dolman AJ, Freibauer A, Valentini R (eds) The continental scale greenhouse gas balance of Europe. Springer, New York, pp 153-190

Seyferth U (1998) Effects of soil temperature and moisture on carbon and nitrogen mineralisation in coniferous forests. Department of Ecology and Environmental Research, Swedish University of Agricultural Sciences, Uppsala

Smith P (2004) How long before a change in soil organic carbon can be detected? Glob Chang Biol 10:1878-1883

Søe ARB, Buchmann N (2005) Spatial and temporal variations in soil respiration in relation to stand structure and soil parameters in an unmanaged beech forest. Tree Physiol 25:1427-1436

Subke JA, Reichstein M, Tenhunen J (2003) Explaining temporal variation in soil $\mathrm{CO}_{2}$ efflux in a mature spruce forest in Southern Germany. Soil Biol Biochem 35:1467-1483

Subke JA, Inglima I, Cotrufo MF (2006) Trends and methodological impacts in soil $\mathrm{CO}_{2}$ efflux partitioning: a metaanalytical review. Glob Chang Biol 12:921-943

Tang J, Baldocchi DD, Xu L (2005) Tree photosynthesis modulates soil respiration on a diurnal time scale. Glob Chang Biol 11:1298-1304

Van Gorsel E, Leuning R, Cleugh HA, Keith H, Suni T (2007) Nocturnal carbon efflux: reconciliation of eddy covariance and chamber measurements using an alternative to the $\mathrm{u}(*)$-threshold filtering technique. Tellus B Chem Phys Meteorol 59:397-403

von Lützow M, Kögel-Knabner I, Ekschmitt K, Flessa H, Guggenberger G, Matzner E, Marschner B (2007) SOM fractionation methods: relevance to functional pools and to stabilization mechanisms. Soil Biol Biochem 39: 2183-2207

Wilczak JM, Oncley SP, Stage SA (2001) Sonic anemometer tilt correction algorithms. Boundary-Layer Meteorol 99:127-150

WRB IWG (2007) World reference base for soil resources 2006, first update 2007. FAO, Rome 